\title{
ASSESSMENT OF SOIL SUSCEPTIBILITY TO EROSION USING THE EPM AND RUSLE MODELS: THE CASE OF VENETIKOS RIVER CATCHMENT
}

\author{
EFTHIMIOU N. ${ }^{1}$ \\ LYKOUDI E. $^{2}$ \\ PANAGOULIA D. ${ }^{3}$ \\ KARAVITIS C. ${ }^{1}$
}

\author{
${ }^{1}$ Agricultural University of Athens \\ Department of Natural Resources Management and Engineering \\ Faculty of Water Resources Management \\ lera Odos 75, Athens, Greece \\ ${ }^{2}$ National Technical University of Athens \\ School of Mining and Metallurgical Engineering \\ Faculty of Geological Sciences, Heroon Polytechniou 9 \\ 15780 Zografou, Greece \\ ${ }^{3}$ National Technical University of Athens, School of Civil Engineering \\ Faculty of Water Resources and Environmental Engineering \\ Heroon Polytechniou 9, 15780 Zografou, Greece
}

Received: $23 / 11 / 2015$

Accepted: 29/12/2015

*to whom all correspondence should be addressed:

Available online: $26 / 01 / 2016$

e-mail: efthimiounik@yahoo.com

\section{ABSTRACT}

The study aims to evaluate soil erosion and investigate its spatial distribution by applying two empirical models, namely the Erosion Potential Model (EPM), also known as Gavrilovic method, and the RUSLE model at Venetikos River catchment, the largest and most important tributary of Aliakmonas River, located at Western Macedonia, Northern Greece. To that end, a GIS-based evaluation is adopted, leading to a more accurate result. The models were implemented both annually and inter-annually. The results were compared with the catchment's "actual" mean annual sediment yield, computed by the sediment discharge measurements conducted on a monthly basis at its outlet, namely Grevena Bridge, by the Greek Public Power Corporation (PPC) during the time period from 1965 to 1982. The Gavrilovic model slightly underestimated the outcome in comparison to the RUSLE methodology which attributed relatively more accurate results, yet performed quite similarly at both time scales. The two approaches simulated the phenomenon quite satisfactory, showing acceptable precision and allowing identification of the most susceptible to erosion and degradation areas, constituting important predictive tools for soil and environmental management in this region.

Keywords: Gavrilovic, EPM, RUSLE, erosion, Venetikos

\section{Introduction}

Soil erosion, defined as the wearing away of the top soil layer, is a long-term natural phenomenon that has been largely responsible for shaping the physical landscape through distributing the materials produced by geomorphic processes. It occurs when the rainfall impact detaches and removes soil particles, either directly by means of rain splash or indirectly by means of runoff (inter-rill, rill, gully erosion). 
Soil erosion, sediment transport and deposition processes are principally determined by four main factors, namely soil erodibility, climate, topography and land use, while their intensity can be exacerbated by human activities such as agricultural practices, deforestation etc.

The assessment of soil erosion and sediment transport in hydrological catchments is imperative, in different temporal and spatial scales, in order to protect and preserve soil as long as technical constructions such as irrigation dams, hydroelectric projects and flood attenuation structures (Panagoulia and Dimou, 2005).

This need has led to the development of different simulation models with varying accuracy and complexity \{empirical (based on the correlation of field measurements and mathematical formulas by means of regression analysis), stochastic, deterministic (physically based, conceptual)\} as well as or other e.g. indicator (biological, physical, social, economic) based methodological approaches (Salvati et al., 2014).

Empirical models are widely applied, especially in countries where the availability of input data is often scarce and the validity ambiguous (such as Greece), because of their simplicity and ease of use, having less input data and computations demands than the comprehensive ones.

One of the most widely accepted and applied empirical models, due to its relative simplicity and robustness on the basis of a standardized lumped approach to catchment scale, is the Universal Soil Loss Equation (USLE), developed by Wischmeier and Smith (1978). The model estimates soil loss per unit of area, taking into account climatological (rainfall-runoff erosivity), pedological (soil erodibility), topographic (slope length and steepness) anthropogenic (cover management and supporting conservation practice) parameters which are further supported by land cover data. Its Revised form (RUSLE) (Renard et al., 1991) holds the initial equation structure, yet its individual factors underwent through several modifications. The latter are based on an extensive review of the USLE and its data base, analysis of data not previously included in the equation, and theory describing fundamental hydrologic and erosion processes (Renard et al., 1991; Renard et al., 1994).

Moreover, a widespread empirical model is the Erosion Potential Model (EPM), also known as Gavrilovic method (Gavrilovic, S., 1962; 1970; 1972), as long as its modifications (Lazarevic, 1968a; 1985). The method takes under consideration six factors, depending on surface geology and soil properties (y coefficient/ erodibility factor), topographic features (mean slope, J), climatic factors \{mean annual rainfall $(\mathrm{h})$, mean annual temperature (t) $\}$, land use type and distribution ( $x$ coefficient/ soil protection factor) and the catchment's degree of erosion ( $\phi$, erosion and stream network development coefficient). It has been widely implemented throughout the Balkans as well as in other countries \{Serbia (Gavrilovic Z., 1988), Croatia (Petras et al., 2005), Slovenia (Zemljic, 1971), Germany (De Cesare et al., 1998), Italy (Fanetti and Vezzoli, 2007; De Vente et al., 2006), Argentina (Rafaelli et al., 1998), Belgium (De Vente and Poesen, 2005), Greece (Emmanouloudis and Filippidis, 2002; Emmanouloudis et al., 2003; Stefanidis et al., 1998; Kalinderis et al., 2009)\}, providing reliable results on qualifying soil erosion severity, estimating mean annual soil loss/ sediment yield as well as implementing torrent regulation and other erosion control measures.

Considering the above, this study aimed to evaluate the performance of EPM and RUSLE at the Venetikos River catchment, located at Western Macedonia, Northern Greece. The Venetikos River was selected for the study purposes, by being the largest and most important tributary of Aliakmonas River, contributing to the overall development of the surrounding area in terms of meeting with the irrigation needs and sustaining the agricultural production, as long as the sediment delivery issues posed by the imminent construction of the "Elafi" damn.

The results were compared to the catchment's "actual" mean annual sediment yield, computed by the sediment discharge measurements conducted on a monthly basis at its outlet, namely Grevena Bridge, by the Greek Public Power Corporation (PPC) during the time period from 1965 to 1982.

The models were implemented in a GIS-based environment, with each factor being described by the form of a digital map. Such delineation is adopted considering the spatial distribution of the input data as well as the overall phenomenon development in a catchment, leading to a more accurate result. The digital 
maps derive from the catchment's digital elevation model (DEM) as long as geological and land-use maps, taking also into account data field measurements and information available in the international literature. The digital layers are then overlaid in order to calculate soil loss in the watershed.

\section{Data and methods}

\subsection{Study Area}

The catchment of Venetikos River, the major tributary of Aliakmonas River, is located at Western Macedonia, Northern Greece, resting almost entirely over the Grevena Prefecture (Fig. 1).

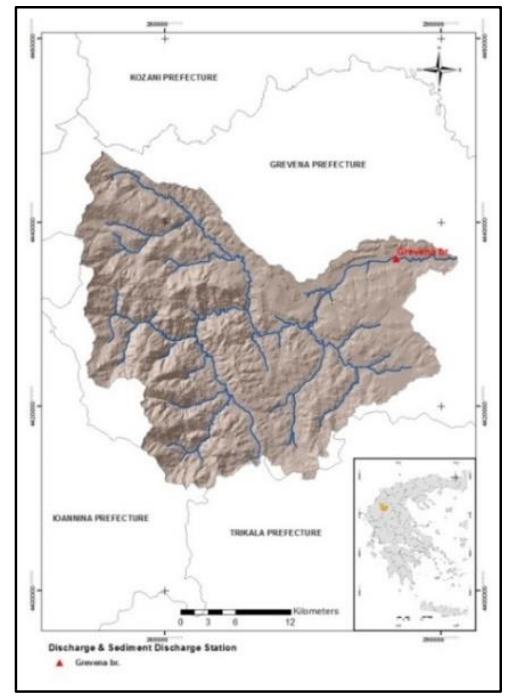

Figure 1. Study area location

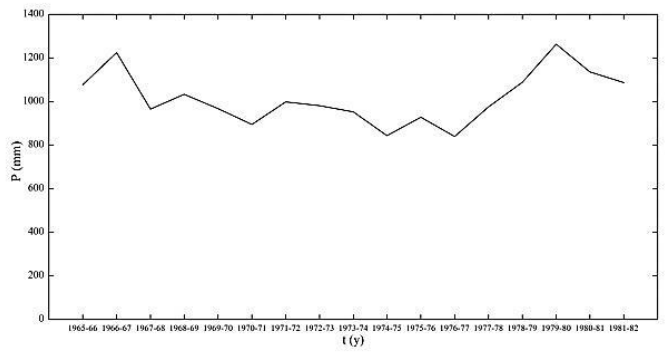

Mean annual precipitation $(\mathrm{mm})$

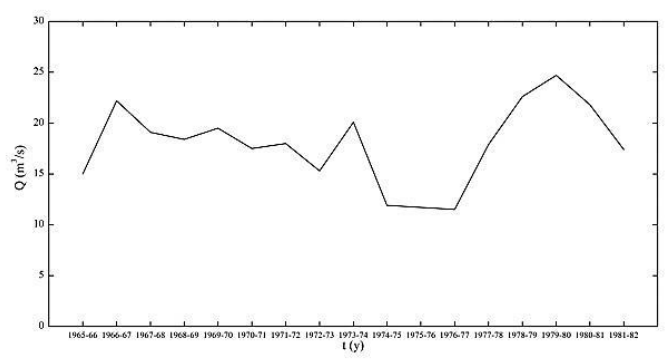

Mean annual discharge $\left(\mathrm{m}^{3} \mathrm{y}^{-1}\right)$

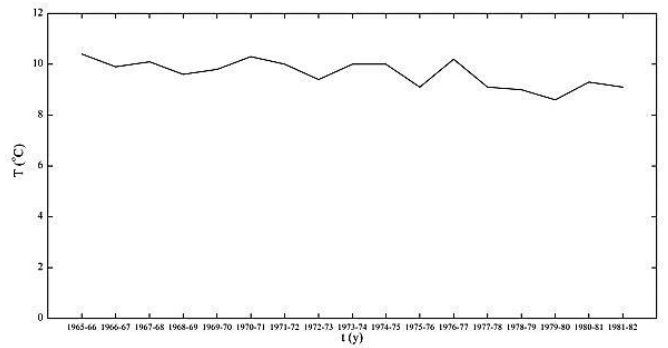

Mean annual temperature $\left({ }^{\circ} \mathrm{C}\right)$

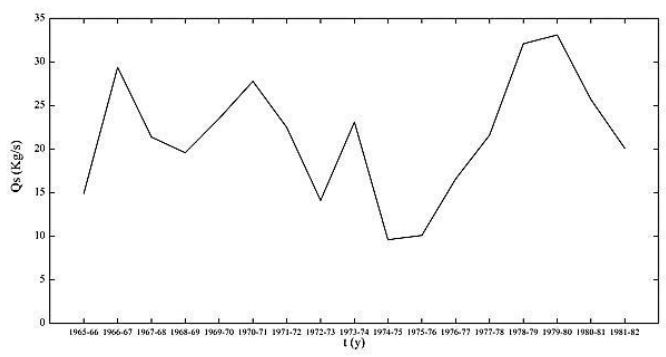

Mean annual sediment discharge $\left(\mathrm{Kg} \mathrm{s}^{-1}\right)$

Figure 2. Mean annual precipitation, temperature, discharge, sediment discharge values 
The basin is mountainous, with intense topographical variations. It has an almost circular shape covering an area of $855.23 \mathrm{Km}^{2}$. The elevation ranges from 437.76 to $2,240.0 \mathrm{~m}$ with the mean elevation being $1,008.71 \mathrm{~m}$. The catchment has a dense hydrographic network including four main streams, emanating from the eastern part of the Pindus mountain range. The main and longest one is $53.9 \mathrm{Km}$ long with an average slope of $1.5 \%$ (Panagoulia et al., 2004). For the time period from 1965 to 1982 mean annual values of discharge $(Q)$, sediment discharge $\left(Q_{s}\right)$, rainfall $(P)$ and temperature $(T)$ are estimated equal to $17.9 \mathrm{~m}^{3} \mathrm{sec}^{-1}, 21.5 \mathrm{Kg} \mathrm{sec}^{-1}, 1015.1 \mathrm{~mm}$ and $10.1{ }^{\circ} \mathrm{C}$, respectively. The discharge and sediment discharge measurements have been conducted on a daily and monthly basis respectively, by the Greek Public Power Corporation (PPC), at the outlet of the catchment namely Grevena bridge (Latitude: $21^{\circ} 29^{\prime} 00^{\prime \prime} \mathrm{N}$, Longitude: $40^{\circ} 03^{\prime} 00^{\prime \prime} E$, Elevation: $468 \mathrm{~m}$ ).

\subsection{The Erosion Potential Model (EPM)}

According to the EPM, the annual volume of detached soil due to surface erosion is calculated by Eq.1.

$$
W=T \cdot h \cdot \pi \cdot \sqrt{z^{3}} \cdot F
$$

where $\mathrm{W}$ is the average annual erosion $\left(\mathrm{m}^{3}\right.$ year $\left.{ }^{-1}\right), \mathrm{T}$ is the temperature coefficient, $\mathrm{h}$ is the mean annual rainfall $(\mathrm{mm}), \mathrm{F}$ is the catchment area $\left(\mathrm{Km}^{2}\right)$, and $\mathrm{z}$ is the erosion coefficient.

The temperature coefficient $(\mathrm{T})$ is calculated by Eq. 2 .

$$
\mathrm{T}=\sqrt{\left(\frac{\mathrm{t}^{0}}{10}+0.1\right)}
$$

where $\mathrm{t}$ is the mean annual temperature $\left({ }^{\circ} \mathrm{C}\right)$.

The erosion coefficient (z), being the measure of intensity or density of erosion processes (Staut, 2004), is calculated by Eq. 3. The coefficient is presented classified as shown in Table 1 (Zemljic, 1971).

$$
z=x \cdot y \cdot(\phi+\sqrt{\jmath})
$$

where $\mathrm{x}$ is the soil protection coefficient, $\mathrm{y}$ is the soil erodibility coefficient, $\phi$ is the erosion and stream network development coefficient, $\mathrm{J}$ is the average slope of the watershed (\%).

Table 1. Classification of $z$ coefficient values

\begin{tabular}{lc}
\hline \multicolumn{1}{c}{ Erosion Intensity } & $\mathbf{z}$ \\
\hline Very low & $<0.19$ \\
\hline Low & $0.20-0.40$ \\
\hline Moderate & $0.41-0.70$ \\
\hline High & $0.71-1.00$ \\
\hline Very High & $>1.00$ \\
\hline
\end{tabular}

Soil erodibility coefficient (y) (dependent on catchment's geology) can be described as the inverse value of the resistance of soil to erosion due to the erosive force of precipitation. Its values are determined through laboratory experiments or field measurements. Soil protection coefficient $(x)$ (dependent on catchment's land use and vegetation cover) consists of two independent coefficients \{land use coefficient (x) (depends on land category, characteristics of vegetation association and degree of vegetation cover) and vegetation cover coefficient (a) (depends on the measures taken to reduce erosion activities, mainly in agriculture)\} treated as one, representing the numerical assessment of the protection of an area against precipitation and erosion. Coefficient $\phi$ stands for the degree of expressed erosion processes (visibly characterized) in the basin, with its value ranging between 0.1 and 1 (Gavrilovic S., 1962; 1970; Gavrilovic Z., 1998; Lazarevic, 1968a; 1985; Staut, 2004; De Vente and Poesen, 2005) (Table 2). 


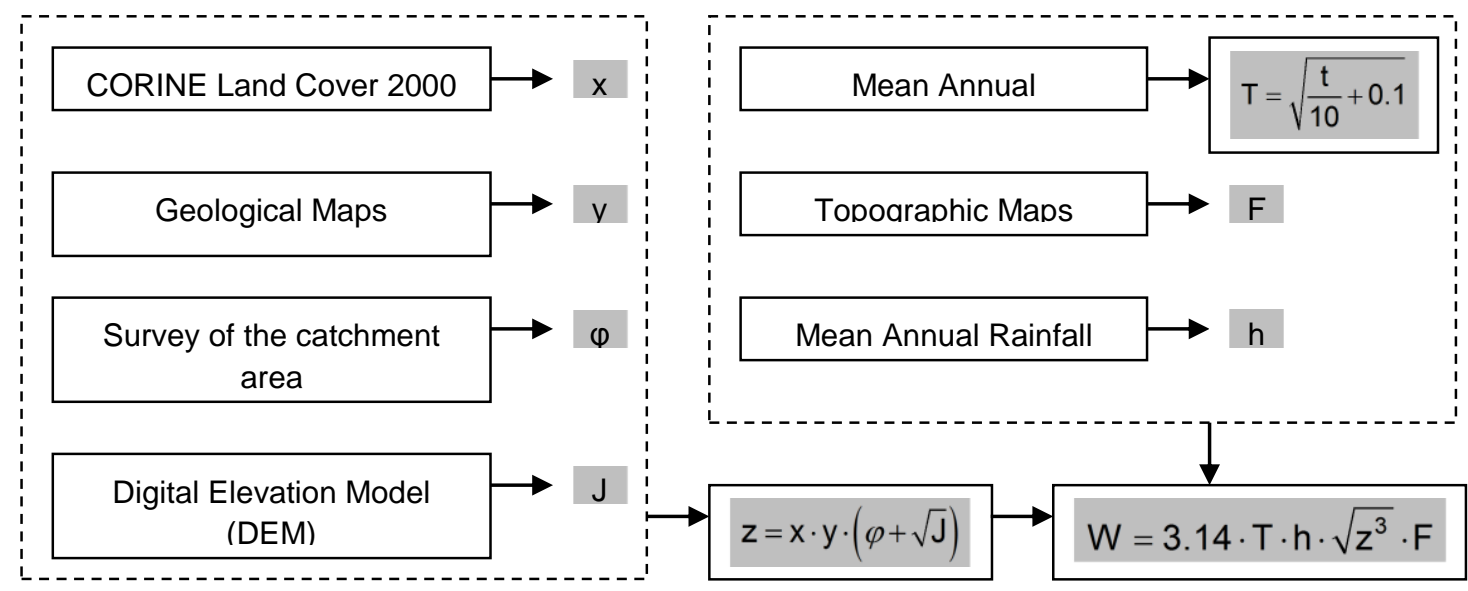

Figure 3. EPM flowchart

Table 2. EPM coefficient values

\begin{tabular}{lc}
\hline \multicolumn{1}{c}{ Coefficient of Soil Cover } & $\mathbf{x}$ \\
\hline Mixed and dense forest & $0.05-0.20$ \\
\hline Thin forest with grove & $0.05-0.20$ \\
\hline Coniferous forest with little grove, scarce bushes, bushy prairie & $0.20-0.40$ \\
\hline Damaged forest and bushes, pasture & $0.40-0.60$ \\
\hline Damaged pasture and cultivated land & $0.60-0.80$ \\
\hline \multicolumn{1}{c}{ Coefficient of soil resistance } & $0.80-1.00$ \\
\hline Hard rock, erosion resistant & $\mathbf{y}$ \\
\hline Rock with moderate erosion resistance & $0.20-0.60$ \\
\hline Weak rock, schistose, stabilized & $0.60-1.00$ \\
\hline Sediments, moraines, clay and other rock with little resistance & $1.00-1.30$ \\
\hline Fine sediments and soils without erosion resistance & $1.30-1.80$ \\
\hline \multicolumn{1}{c}{ Coefficient of type and extent of erosion } & $1.80-2.00$ \\
\hline Little erosion on watershed & $\mathbf{\phi}$ \\
\hline Erosion in waterways on 20-50\% of the catchment area & $0.10-0.20$ \\
\hline Erosion in rivers, gullies and alluvial deposits, karstic erosion & $0.30-0.50$ \\
\hline 50-80\% of catchment area affected by surface erosion and & $0.60-0.70$ \\
\hline landslides & $0.80-0.90$ \\
\hline Whole watershed affected by erosion & $0.90-1.00$ \\
\hline
\end{tabular}

Only a fraction of the total sediment volume, produced within a catchment due to soil erosion, results to the catchment's outlet, since a large portion of that amount is deposited within, during the sediment's course towards the water bodies. The effective sediment transported by the stream to the outlet of the catchment \{actual sediment yield, $\mathrm{G}\left(\mathrm{m}^{3}\right.$ year $\left.{ }^{-1}\right)$ \} is determined by the Retention Coefficient (DR), introduced by the EPM (Eq. 4).

\section{$\mathrm{G}=\mathrm{DR} \cdot \mathrm{W}$}

The DR is estimated using the following equation (Zemljic, 1971):

$$
D R=\frac{\sqrt{O \cdot D}\left(L+L_{i}\right)}{F(L+10)}
$$


where $O$ is the perimeter of the catchment $(\mathrm{Km}), \mathrm{D}$ is the average height distance of the catchment $(\mathrm{Km})$, $L$ is the length of the principal waterway $(K m), L_{i}$ is the length of the secondary waterway $(K m)$ and $F$ is the catchment area $(\mathrm{Km})$. Average height distance is calculated as (Globevnik et al., 2003):

$$
D=H_{r}-H_{\min }=\left(H_{\max }-H_{\min }\right)-H_{\min }
$$

where $H_{r}(m)$ is the maximum relief of the catchment (defined as the difference between the maximum $\left(H_{\max }, \mathrm{m}\right)$ and the minimum $\left(\mathrm{H}_{\min }, \mathrm{m}\right)$ elevation).

\subsection{The Revised Universal Soil Loss Equation (R.U.S.L.E)}

Soil erosion is estimated as the product of six major erosion factors (Eq. 7).

$$
A=R \cdot K \cdot L S \cdot C \cdot P
$$

where $A$ is the average soil loss per unit of area $\left(\mathrm{t} \mathrm{ha}^{-1}\right), \mathrm{R}$ is the rainfall erosivity factor ( $\left.\mathrm{MJ} \mathrm{mm} \mathrm{ha} \mathrm{m}^{-1} \mathrm{~h}^{-1} \mathrm{yr}^{-1}\right)$, $\mathrm{K}$ is the soil erodibility factor ( $\mathrm{t} \mathrm{h} \mathrm{MJ} \mathrm{mm}^{-1}$ ), LS is the topographic factor (dimensionless) which includes slope length factor (dimensionless) and slope steepness factor (dimensionless), $\mathrm{C}$ is the cover management factor (dimensionless), and $\mathrm{P}$ is the support (or conservation) practice factor (dimensionless).

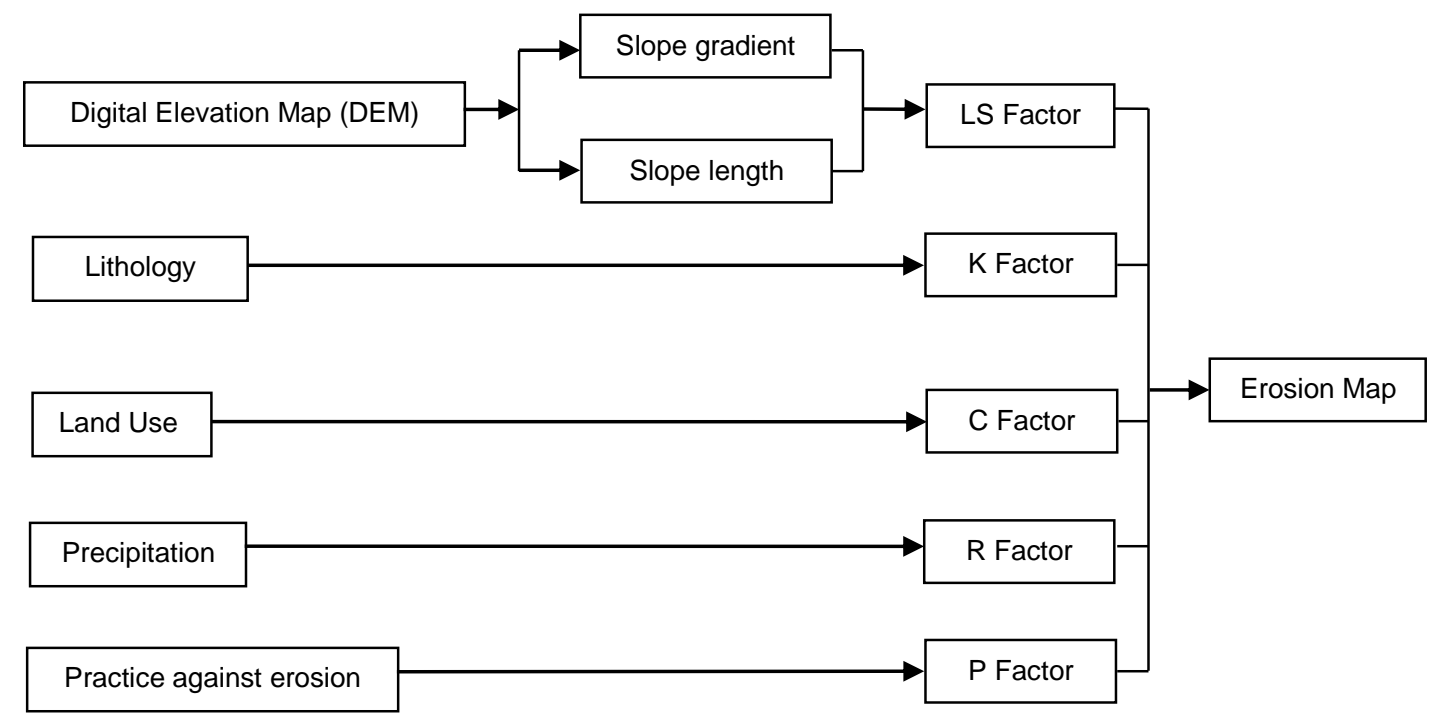

Figure 4. RUSLE flowchart

\subsection{Climatic data}

Temperature data (daily maximum, minimum, mean) are only available from Krania station (Latitude:

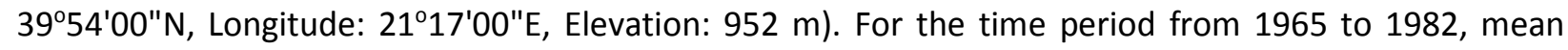
annual temperature is estimated equal to $10.1^{\circ} \mathrm{C}$. Since this value refers to the location and elevation of the specific station, it needs to be normalized to the catchment's total area and mean elevation. Considering there is only one station located within the catchment area, this can be achieved by the use of Eq. 8 (Koytsoyiannis and Xantopoulos, 1999):

$$
T_{s}=T_{\sigma}-\alpha\left(z_{s}-z_{\sigma}\right)
$$

where $T_{s}\left({ }^{\circ} \mathrm{C}\right)$ is the catchment's normalized mean temperature, $T_{\sigma}\left({ }^{\circ} \mathrm{C}\right)$ is the station's mean temperature, $\alpha\left({ }^{\circ} \mathrm{C} \mathrm{m}^{-1}\right)$ is the temperature gradient ssince no other information is available, the typical value of the variable was used $\left.\left(0.0065^{\circ} \mathrm{C} \mathrm{m}^{-1}\right)\right\}, z_{\mathrm{s}}$ and $z_{\sigma}$ are the catchment's mean elevation and station elevation, respectively.

In sight of the above $T_{s}$ is calculated equal to $9.53^{\circ} \mathrm{C}$. 
The watershed's normalized mean annual precipitation \{surface reduction (Thiessen interpolation), mean elevation correction (precipitation gradient)\} (Fig. 5) was calculated considering the daily precipitation data from eight gauging stations, namely Karpero, Kipoureio, Spilaio, Krania, Grevena, Agiofyllo, Malakasio and Pentalofos for the time period 1965-1982 (Table 3), equal to 1,015.1 mm.

Table 3. Mean Annual Precipitation (P) and Erosivity factor ( $R$ )

\begin{tabular}{lcccccc}
\hline \multicolumn{1}{c}{ Station } & Lat. & Long & Elev. $(\mathbf{m})$ & Records & $\mathbf{P}(\mathbf{m m})$ & $\mathbf{R}\left(\mathbf{M J ~} \mathbf{~ m m ~ h a}^{-\mathbf{1}} \mathbf{h}^{-\mathbf{1}} \mathbf{y}^{-\mathbf{1}}\right)$ \\
\hline Karpero & $21^{\circ} 38^{\prime}$ & $39^{\circ} 57^{\prime}$ & 510 & $1965-1982$ & 619.0 & 804.69 \\
\hline Kipoureio & $21^{\circ} 22^{\prime}$ & $39^{\circ} 57^{\prime}$ & 868 & $1965-1982$ & 963.0 & $1,251.93$ \\
\hline Spilaio & $21^{\circ} 17^{\prime}$ & $40^{\circ} 00^{\prime}$ & 900 & $1965-1982$ & 923.6 & $1,200.68$ \\
\hline Krania & $21^{\circ} 17^{\prime}$ & $39^{\circ} 54^{\prime}$ & 952 & $1965-1982$ & 932.2 & $1,211.84$ \\
\hline Grevena & $21^{\circ} 26^{\prime}$ & $40^{\circ} 05^{\prime}$ & 524 & $1965-1982$ & 837.5 & $1,088.77$ \\
\hline Agiofyllo & $21^{\circ} 34^{\prime}$ & $39^{\circ} 52^{\prime}$ & 581 & $1965-1982$ & 734.0 & 954.22 \\
\hline Malakasio & $21^{\circ} 17^{\prime}$ & $39^{\circ} 47^{\prime}$ & 847 & $1965-1982$ & $1,241.0$ & $1,613.32$ \\
\hline Pentalofos & $21^{\circ} 09^{\prime}$ & $40^{\circ} 12^{\prime}$ & 1040 & $1965-1982$ & 989.5 & $1,286.41$ \\
\hline
\end{tabular}

\subsection{Land use data}

The land use-land cover map derived from the CORINE Land Cover 2000 database (Table 4, Fig. 5).

Table 4. Land use - CORINE Land Cover 2000 Classification

\begin{tabular}{cccc}
\hline Code & Description & Area $\left.\mathbf{~ K m}^{\mathbf{2}}\right)$ & Cover (\%) \\
\hline 112 & Discontinuous Urban Fabric & 1.18 & 0.14 \\
\hline 211 & Non-irrigated arable land & 37.86 & 4.43 \\
\hline 231 & Pastures & 0.29 & 0.03 \\
\hline 242 & Complex cultivation patterns & 17.53 & 2.05 \\
\hline 243 & $\begin{array}{c}\text { Land principally occupied by agriculture with } \\
\text { significant areas of natural vegetation }\end{array}$ & 98.75 & 11.55 \\
\hline 311 & Broad-leaved forest [a] & 167.01 & 19.53 \\
\hline 312 & Coniferous forest $^{\text {a] }}$ & 138.39 & 16.18 \\
\hline 313 & Mixed forest ${ }^{\text {a] }}$ & 111.14 & 13.00 \\
\hline 321 & Natural grassland & 64.51 & 7.54 \\
\hline 323 & Sclerophyllous vegetation & 10.32 & 1.21 \\
\hline 324 & Transitional woodland/shrubs & 203.65 & 23.81 \\
\hline 331 & Beaches, dunes, sand plains & 2.18 & 0.25 \\
\hline 333 & Sparsely vegetated areas & 0.19 & 0.02 \\
\hline 511 & Water courses & 2.24 & 0.26 \\
\hline & & 855.23 & 100 \\
\hline
\end{tabular}

[a] Forests [broad-leaved, coniferous, mixed] are not treated as a single set and therefore the $\mathrm{C}, \mathrm{x}$ coefficient varies. Mixed forests are attributed with the lowest value, since they do not display the same hydrological characteristics. Broad-leaved forests [beech, oak, chestnut, plane tree, hazel etc] are attributed with the highest value, since they thrive in areas with high soil moisture values (infiltration less runoff - less erosion). Coniferous forests [cedar, pine, cypress, fir, etc] are attributed with the mean coefficient value since they thrive in areas where surface runoff is favored (less Infiltration - drier ground - more erosion).

\subsection{Geological data}

The geological maps of the Greek Institute of Geological and Mining Exploration (IGME) namely Pentalofo, Panagia, Metsovo, Grevena, Knidi and Ayiofyllo in a scale of 1:50.000 were used, in order to initially group the individual geological formations of Venetikos' basin into the final integrated ones and create the corresponding map (Fig. 5). 
The new codes of the integrated geological formations were attributed based on the original codes assigned by IGME, while the ranking within each team was based upon the particular geological age and lithology (corresponding to the vulnerability to disintegration and the capability of sediment production). The formations were anew grouped into three major geological age groups (Quaternary, Neogene, PreNeogne), with the latter including the formations of the Paleogene, Cretaceous, Jurassic, Triassic, Paleozoic periods.

\subsection{Morphometric attributes}

The morphometric attributes of Venetikos' River catchment were assessed considering its DEM ( $25 \mathrm{~m}^{2}$ grid cells, 25 m contour interval, scale 1:50.000) and stream network properties.

The average slope of the catchment is $23.64 \%$. The highest values occur at areas of high relief and the lowest at the lowlands of the basin, with the latter gradually declining towards the catchment's outlet (Fig. 5).

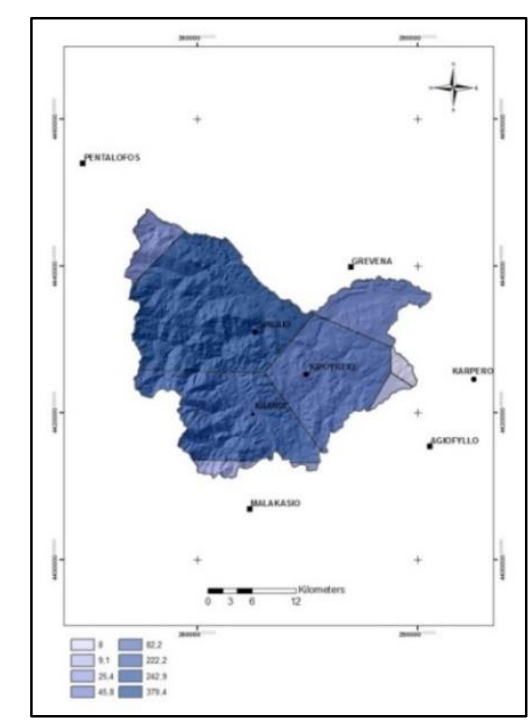

Mean Annual Precipitation-Stations

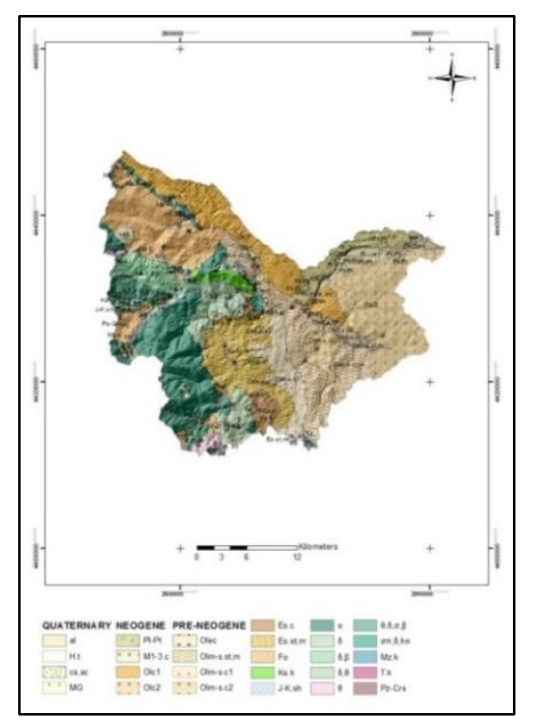

Integrated Geological Formations

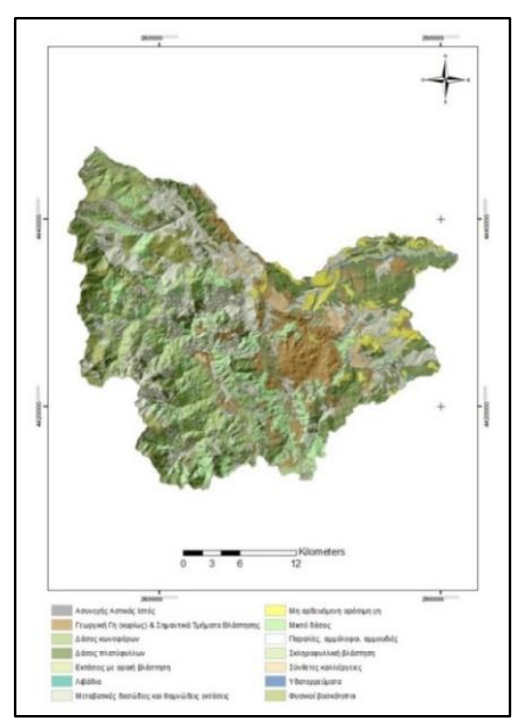

Land use

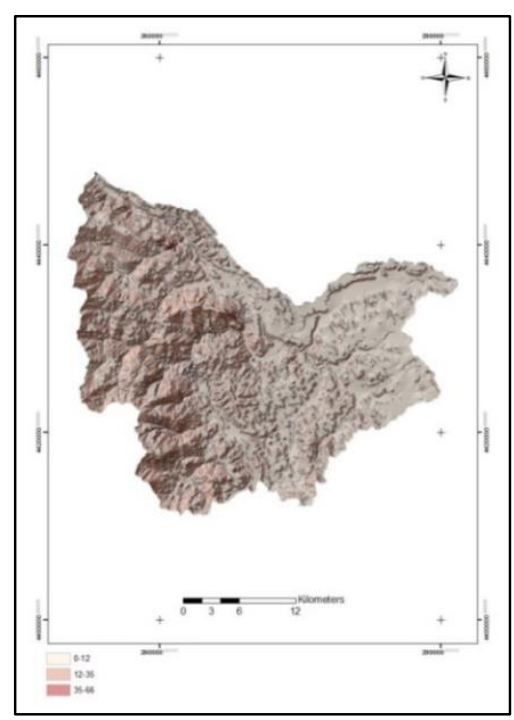

Slope

Figure 5. Input data 


\subsection{EPM implementation}

Concerning the catchment's normalized mean annual temperature $\left(9.53^{\circ} \mathrm{C}\right)$ the temperature coefficient $(T)$ is equal to 1.04 , according to Eq. 2.

In order to determine the erosion coefficient (z), the calculation of the individual factors of Eq. 3 is required.

Concerning the soil protection coefficient $(\mathrm{x})$, a value was assigned to every coded land use occurring in the catchment, according to Table 2 (Fig. 7). The lowest values of the coefficient occur (apart from the non-vegetated urban areas and the water body) at areas of high vegetation cover, suggesting a strongly protective effect of the vegetation cover against soil erosion. The highest values occur at areas of mild or low vegetation cover which are more exposed, thus more prone, to the negative consequences of the phenomenon. The pattern is quite similar to the RUSLE's Cover Manager Factor (C) corresponding one (Fig. 8).

Concerning the soil erodibility coefficient (y), since the classification method followed (IGME) is not suitable for the direct recovery of conclusions relative to the torrential properties of the integrated geological formations, they were moreover grouped according to Table 5 classification, taking under consideration criteria such as the type, degree of intensity, quantity and combination of the torrential phenomena that characterize them (Fig. 6). A value was then assigned to every coded geological formation occurring in the catchment, according to Table 2 (Fig. 7). The highest values of the coefficient occur at the areas close to the catchment's outlet, relatively moderate values to the catchment's lowlands, while the lowest values occur at areas with high relief, on the mountain range of Pindos. The pattern is quite similar to the RUSLE's Soil Erodibility Factor (K) corresponding one (Fig. 8).

Table 5. Torrential-petrological formations according to EPM classification

\begin{tabular}{cc}
\hline Torrential - petrological formation & Gavrilovic classification \\
\hline Flysch $(\mathrm{F})$ & Weak rock, schistose, stabilised \\
\hline Schistose $(\mathrm{G})$ & Weak rock, schistose, stabilised \\
\hline Chalky $(\mathrm{K})$ & Rock with moderate erosion resistance \\
\hline Crystalline-igneous, basic $\left(\mathrm{M}, \mathrm{M}_{2}\right)$ & Rock with moderate erosion resistance \\
\hline Crystalline-igneous, metamorphic $\left(\mathrm{M}, \mathrm{M}_{3}\right)$ & Weak rock, schistose, stabilised \\
\hline Neogene $(\mathrm{S})$ & Sediments, moraines, clay and other rock with little \\
resistance
\end{tabular}

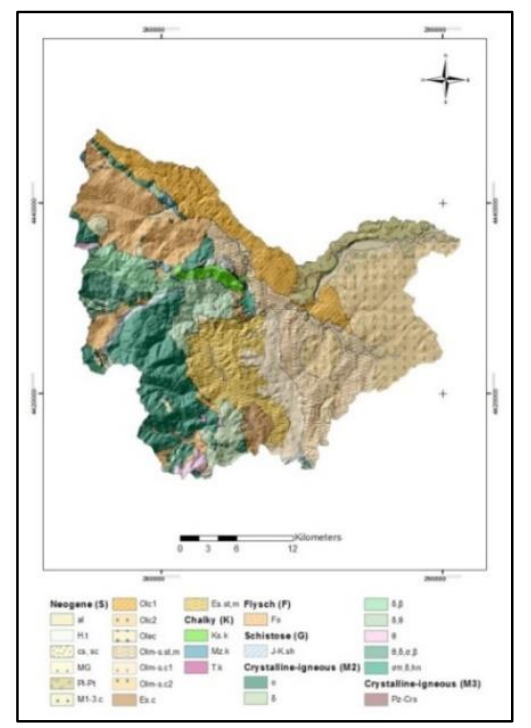

Figure 6. Geology-Integrated Geological Formations (EPM classification) 
Concerning the erosion and stream network development coefficient $(\phi)$, its value was determined after field observation. The geomorphology and the land cover pattern of the catchment (mainly mountainous with more than $80 \%$ of the area, especially the upstream parts, being covered by forests and semi-natural areas according to the CORINE Land Cover categorization) provide protection against erosion. Moreover, the bedrock of the catchment which is not as prone to erosion yields small portions of sediments. Additionally, the mild cultivation and farming techniques practiced in the portion of the catchment being used for agricultural activities ( $18 \%$ of the total area) do not encumber the soil as far its vulnerability to erosion is concerned. In respect to the catchment's aforementioned specific characteristics as far geology, geomorphology and land use is concerned the coefficient takes the value of 0.15 for the whole catchment area.

The basin's average slope (23.64 \%) is introduced as 0.2364 .

Considering the aforementioned individual factors of Eq. $3(x, y, \phi, J)$, the erosion coefficient $(z)$ is calculated and then classified according to Table 1 (Fig. 7). The highest values are located at the lowlands of the basin, due to the corresponding high values of the $x, y$ coefficients occurring at these areas. Slope does not seem to affect the result to the specific areas, not only because of its low values, but also by being degraded since involved to Eq. 3 by its square root.

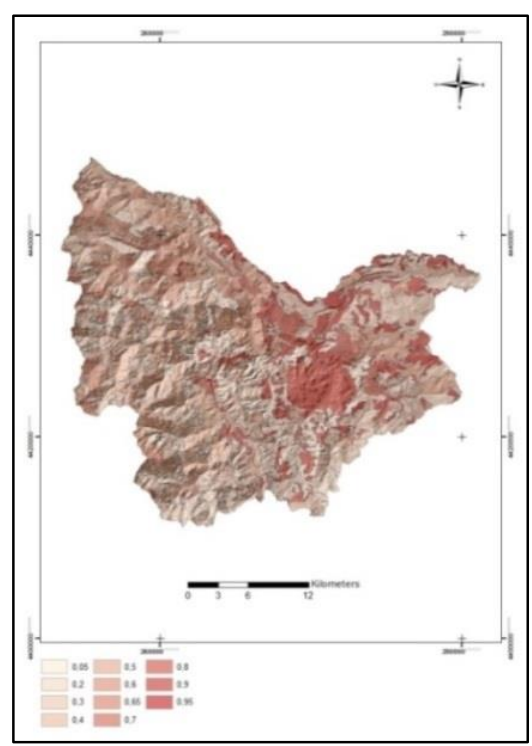

Soil protection coefficient $(x)$

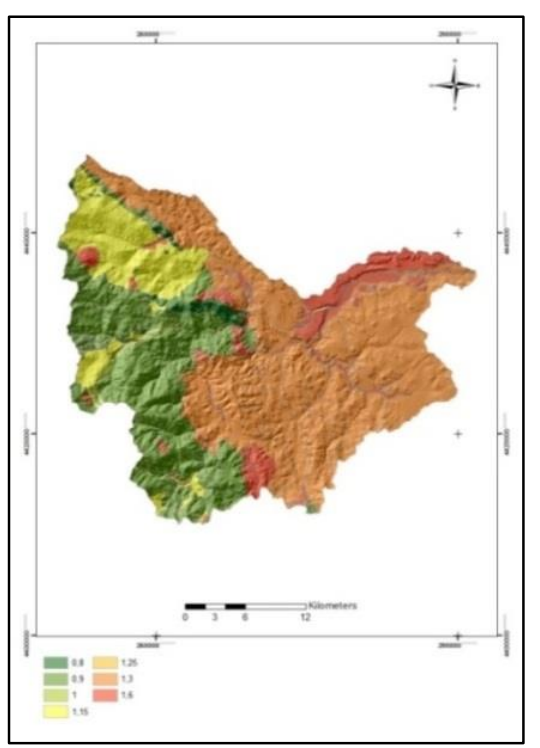

Soil erodibility coefficient $(y)$

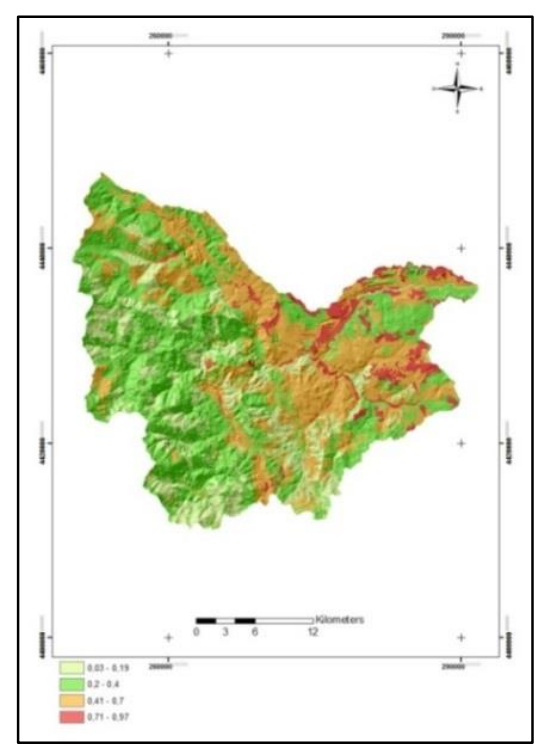

Erosion coefficient $(z)$

Figure 7. EPM coefficients

\subsection{RUSLE implementation}

Concerning the estimation of the Rainfall Erosivity Factor (R), the Van der Knijff et al. (2000) equation was applied (Eq. 9). The "a" factor was considered equal to 1.3.

$$
R=a \cdot P
$$

The $\mathrm{R}$ factor was subsequently calculated for each of the 8 gauging stations given the daily rainfall data for the time period from 1965 to 1982 (Table 3). Its values are higher at the central area of the catchment and decline towards its outer limits (Fig. 8).

Concerning the Soil Erodibility Factor (K), considering the IGME geological maps, each integrated rock formation of the study area was given a $\mathrm{K}$ factor value, based on the rock type and geological age according to international literature, following a similar to the EPM's Soil erodibility coefficient (y) pattern (Fig. 8). 
The Slope Length-Steepness Factor (LS) was estimated considering the catchment's DEM. The highest values of the coefficient occur at areas of high relief and the lowest at the lowlands of the basin, with the latter gradually declining towards the catchment's outlet (Fig. 8).

The land use/land cover map derived from the CORINE Land Cover 2000 database (Table 4). Each coded land use was assigned with a Cover Management Factor (C) coefficient value by considering a literature review (Fig. 8). The pattern is similar to the EPM's soil protection coefficient (x).

Assuming that no support practice occurs at the catchment, since no relative information is available, the $P$ factor was assigned a value equal to 1.0 throughout its area.

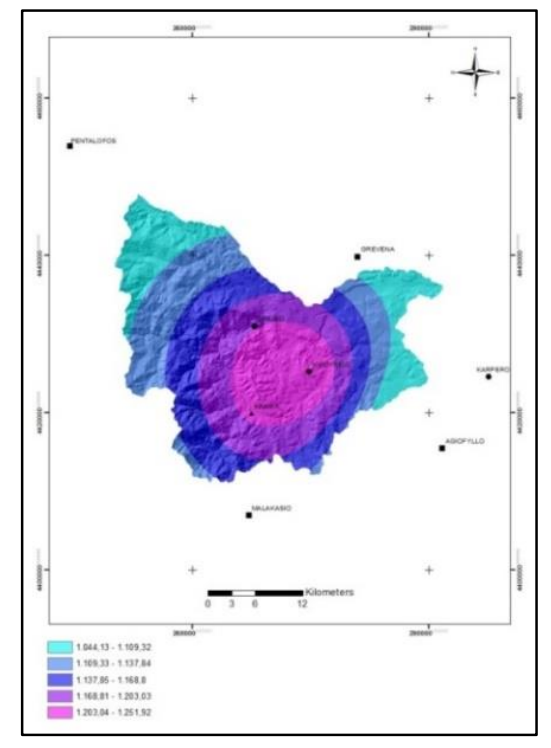

Rainfall Erosivity Factor (R)

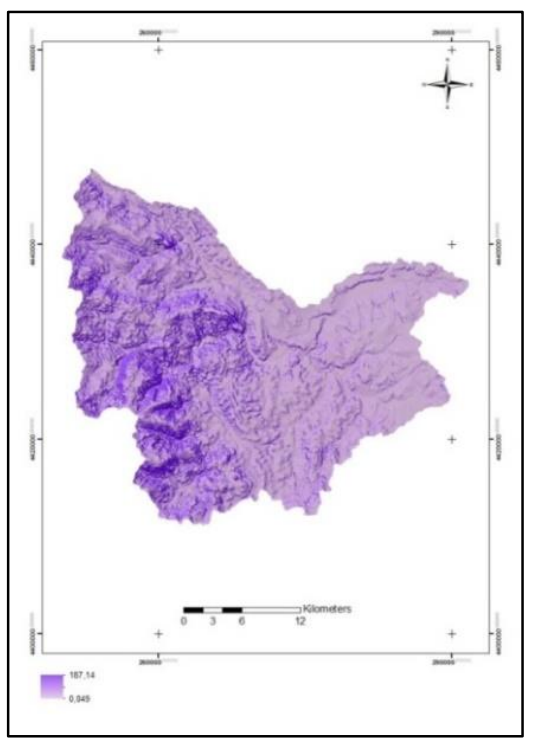

Slope Length-Steepness Factor (LS)

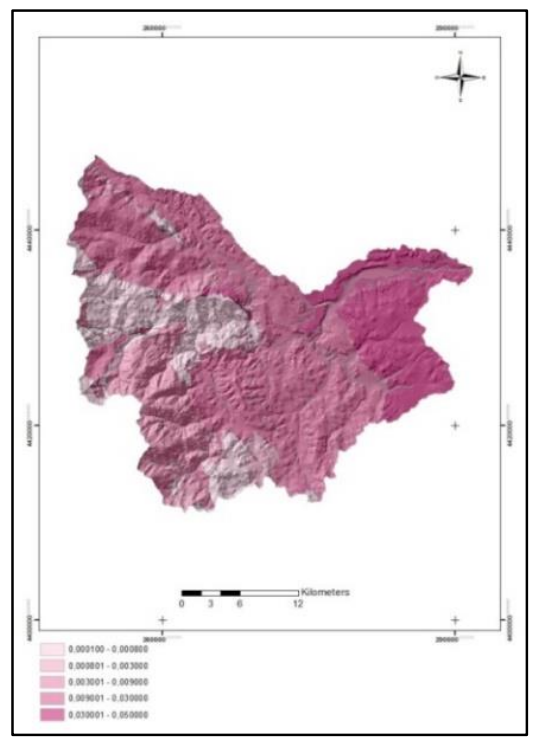

Soil Erodibility Factor (K)

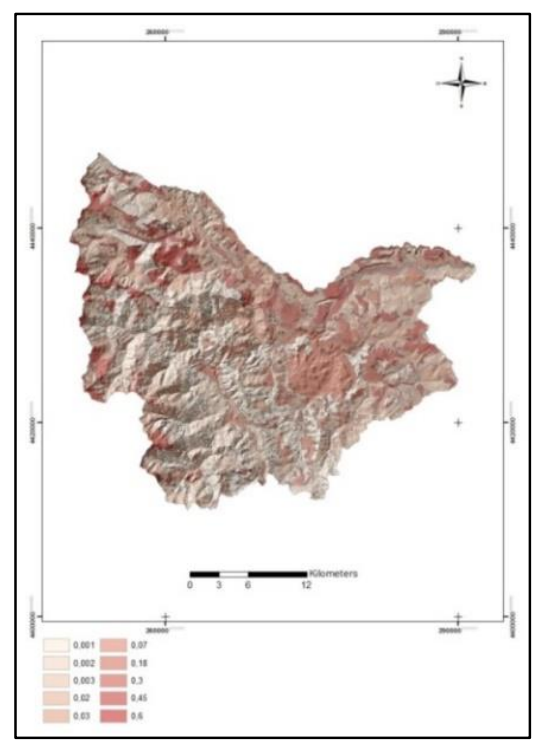

Cover Management Factor (C)

Figure 8. RUSLE individual factors 


\section{Results and discussion}

Concerning the inter-annual implementation of the EPM at the Venetikos River catchment, mean annual (compact) volume of detached soil due to surface erosion (W) was calculated (Eq.1) equal to 687,377.47 $\mathrm{m}^{3} \mathrm{y}^{-1}$.

The result is multiplied to the soil's specific weight value (usually equal to $2.67 \mathrm{t} \mathrm{m}^{-3}$, ranging between 2.65 2.75 $\left.\mathrm{t} \mathrm{m}^{-3}\right)$, in order to be expressed in the same units as the RUSLE ones $\left(\mathrm{t}^{-1}\right)$ and thus allow the

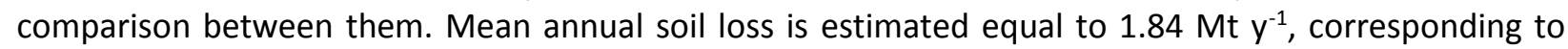
mean annual soil loss per unit area (mean annual gross erosion-it is also referred as "mean annual specific erosion", $\mathrm{w}_{\mathrm{sp}}$ ) equal to $2,145.97 \mathrm{t} \mathrm{Km}^{-2} \mathrm{y}^{-1}$ considering the catchment's area (Fig. 9).

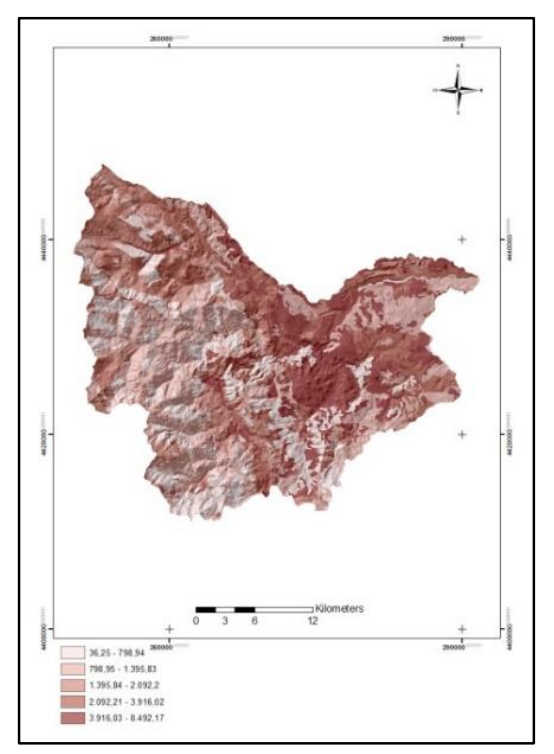

EPM

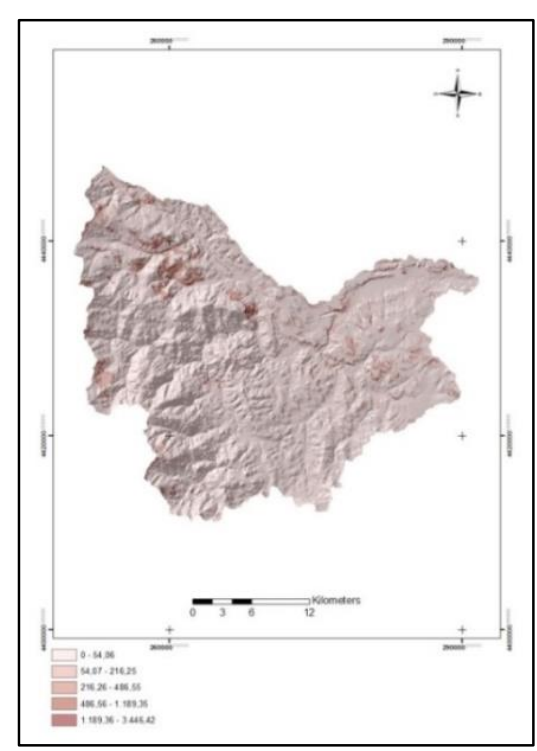

RUSLE

Figure 9. Soil loss per unit area $\left(\mathrm{t} \mathrm{Km}^{-2} \mathrm{y}^{-1}\right)$

According to the EPM, the effective sediment transported to the catchment's outlet is determined by the Retention Coefficient (DR). In respect to the Eq. 5 morphometric characteristics [ $\mathrm{O}=167.54 \mathrm{Km}, \mathrm{D}=1,364.5$ $m(=1.365 \mathrm{Km}), \mathrm{L}=53.9 \mathrm{Km}, \mathrm{L}_{\mathrm{i}}=193.1 \mathrm{Km}, \mathrm{F}=855.23 \mathrm{Km}^{2}$ ], the DR equals to $0.07(7 \%)$. Since that value was considered fairly low, DR was replaced by the catchment's representative Sediment Delivery Coefficient (SDR) (Renfro, 1972), equal to 0.2291 (22.91\%).

SDR was then applied to the mean annual soil loss per unit area, resulting to transported gross erosion at the catchments' outlet (mean annual sediment yield) equal to $491.64 \mathrm{t} \mathrm{Km}^{-2}$. Considering the total catchment area, the result corresponds to mean annual soil loss equal $0.42 \mathrm{Mt} \mathrm{y}^{-1}$.

Table 6. Inter-annual results

\begin{tabular}{ccccccc}
\hline & \multicolumn{3}{c}{ Sediment Discharge (Qs) } & \multicolumn{3}{c}{ Sediment Yield (SY) } \\
\hline & $\mathrm{Kg} \mathrm{s}^{-1}$ & $\mathrm{t}^{-1}$ & $\mathrm{Mt} \mathrm{y}^{-1}$ & $\mathrm{t} \mathrm{ha}^{-1}$ & $\mathrm{t} \mathrm{Km}^{-2}$ & $\mathrm{Kg} \mathrm{m}^{-2}$ \\
\hline PPC & 21.48 & $677,393.28$ & 0.68 & 7.92 & 791.99 & 0.79 \\
\hline EPM & 13.33 & $420,466.76$ & 0.42 & 4.92 & 491.64 & 0.49 \\
\hline RUSLE & 14.59 & $460,261.58$ & 0.46 & 5.38 & 538.17 & 0.54 \\
\hline
\end{tabular}

Concerning the inter-annual implementation of the RUSLE model, mean annual soil loss per unit of area was calculated equal to $2,349.07 \mathrm{t} \mathrm{Km}^{-2} \mathrm{y}^{-1}$ (Fig. 9). Reduced to the total catchment area, the result corresponds to mean annual soil loss equal $2.01 \mathrm{Mt}^{-1}$. Similarly, by applying the SDR to the result, 
transported gross erosion at the catchments' outlet was calculated, equal to $538.17 \mathrm{t} \mathrm{Km}^{-2}$. Considering the total catchment area, the result corresponds to mean annual soil loss equal $0.46 \mathrm{Mt} \mathrm{y}^{-1}$.

Both models were also implemented annually, following the same procedure.

The final results (Table 6, 7-Fig. 10) were significantly lower than their initial estimates, approaching the actual (measured) values of mean annual sediment discharge and yield conducted on a daily and monthly basis respectively by the Greek Public Power Corporation (PPC) during the time period 1965-1982, respectively. Yet, they both underestimate the result in comparison to the measured one (apart from the years 1974-75 and 1975-76) at both time scales. The EPM, while slightly underestimating the results in comparison to the RUSLE methodology, showed acceptable precision and allowed identification of the most susceptible areas to water erosion, constituting an important predictive tool for soil and environmental management in this region.

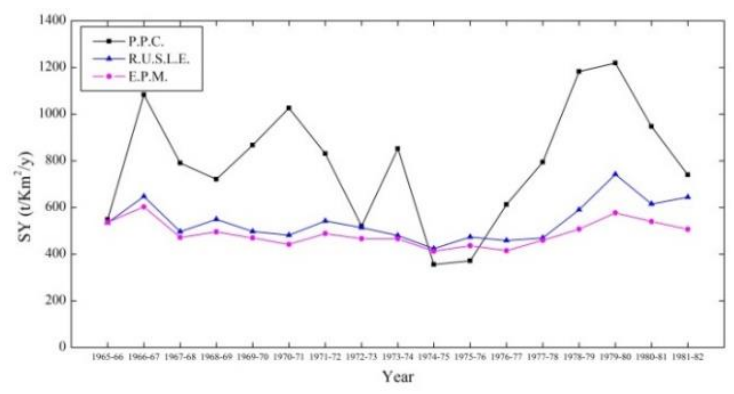

Annual Sediment Yield $\left(\mathrm{t} \mathrm{Km}^{-2} \mathrm{y}^{-1}\right)$

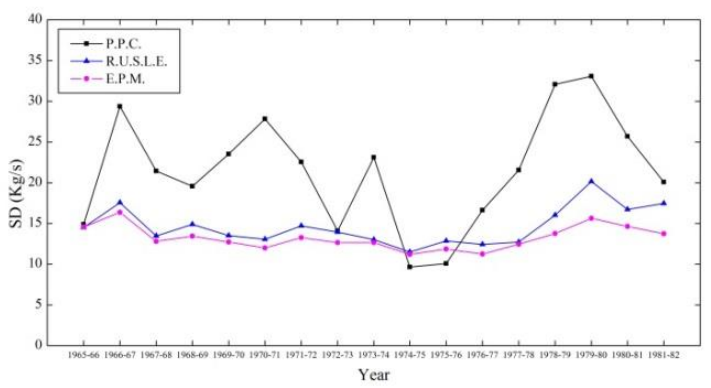

Annual Sediment Discharge $\left(\mathrm{Kg} \mathrm{s}^{-1}\right)$

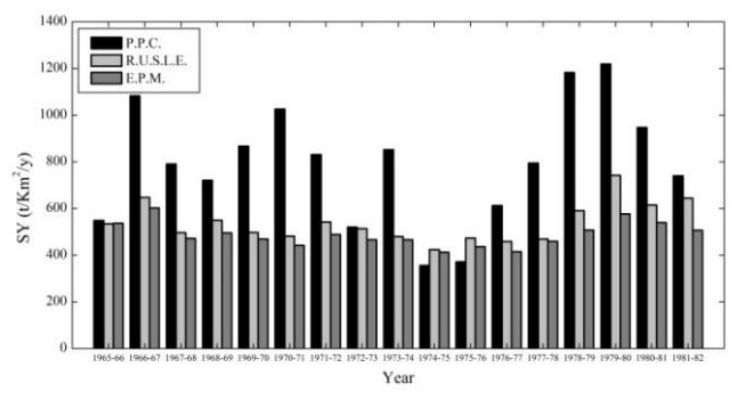

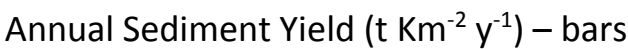

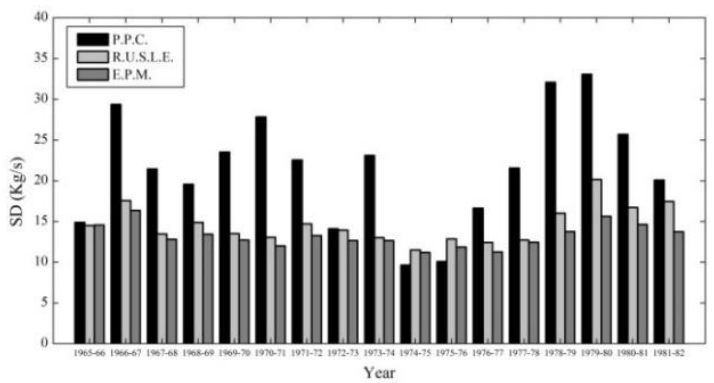

Annual Sediment Discharge $\left(\mathrm{Kg} \mathrm{s}^{-1}\right)-$ bars

Figure 10. Annual results

\section{Conclusions}

The main objective of this study is to apply the EPM and RUSLE models to the Venetikos River catchment, in order to estimate soil erosion and investigate its spatial distribution. The results are compared with each other, as well as to the catchment's "actual" mean annual sediment yield, estimated considering the sediment discharge measurements conducted at its outlet by the Greek Public Power Corporation (PPC).

The Gavrilovic method, slightly underestimated the final results in comparison to the RUSLE methodology which attributed relatively more accurate results. Both models performed quite similarly at both time scales. Moreover, they both attributed underestimated results in comparison to the "actual" (measured) values of mean annual sediment discharge and yield, yet approaching them quite satisfactory.

Overall, the two approaches simulated the phenomenon sufficiently well, showing acceptable precision and allowing identification of the most susceptible to erosion areas. 
Table 7. Annual results

\begin{tabular}{|c|c|c|c|c|c|c|c|c|c|c|c|c|c|c|c|c|c|c|}
\hline & \multicolumn{9}{|c|}{ Sediment Discharge (Qs) } & \multicolumn{9}{|c|}{ Sediment Yield (SY) } \\
\hline & \multicolumn{3}{|c|}{ PPC } & \multicolumn{3}{|c|}{ RUSLE } & \multicolumn{3}{|c|}{ Gavrilovic } & \multicolumn{3}{|c|}{ PPC } & \multicolumn{3}{|c|}{ RUSLE } & \multicolumn{3}{|c|}{ Gavrilovic } \\
\hline & $\mathrm{Kg} \mathrm{s}^{-1}$ & $t y^{-1}$ & Mt $\mathrm{y}^{-1}$ & $\mathrm{Kg} \mathrm{s}^{-1}$ & $t y^{-1}$ & Mt $\mathrm{y}^{-1}$ & $\mathrm{Kg} \mathrm{s}^{-1}$ & $t y^{-1}$ & $M t y^{-1}$ & t ha $^{-1}$ & $\mathrm{t} \mathrm{Km}^{-2}$ & $\mathrm{Kg} \mathrm{m}^{-2}$ & $t_{\text {ha }}^{-1}$ & $\mathrm{t} \mathrm{Km}^{-2}$ & $\mathrm{Kg} \mathrm{m}^{-2}$ & $\mathrm{tha}^{-1}$ & $\mathrm{t} \mathrm{Km}^{-2}$ & $\mathrm{Kg} \mathrm{m}^{-2}$ \\
\hline $1965-66$ & 14.88 & $469,255.68$ & 0.47 & 14.49 & $456,933.02$ & 0.46 & 14.55 & $458,974.94$ & 0.46 & 5.49 & 548.69 & 0.55 & 5.34 & 534.28 & 0.53 & 5.37 & 536.67 & 0.54 \\
\hline $1966-67$ & 29.37 & $926,212.32$ & 0.93 & 17.57 & $554,016.63$ & 0.55 & 16.35 & $515,569.84$ & 0.52 & 10.83 & $1,083.00$ & 1.08 & 6.48 & 647.80 & 0.65 & 6.03 & 602.84 & 0.60 \\
\hline $1967-68$ & 21.44 & $676,131.84$ & 0.68 & 13.46 & $424,508.69$ & 0.42 & 12.80 & $403,599.94$ & 0.40 & 7.91 & 790.58 & 0.79 & 4.96 & 496.37 & 0.50 & 4.72 & 471.92 & 0.47 \\
\hline $1968-69$ & 19.56 & $616,844.16$ & 0.62 & 14.88 & $469,290.22$ & 0.47 & 13.44 & $423,807.91$ & 0.42 & 7.21 & 721.26 & 0.72 & 5.49 & 548.73 & 0.55 & 4.96 & 495.55 & 0.50 \\
\hline $1969-70$ & 23.53 & $742,042.08$ & 0.74 & 13.49 & $425,341.08$ & 0.43 & 12.72 & $401,040.18$ & 0.40 & 8.68 & 867.65 & 0.87 & 4.97 & 497.34 & 0.50 & 4.69 & 468.93 & 0.47 \\
\hline 1970-71 & 27.83 & $877,646.88$ & 0.88 & 13.04 & $411,161.80$ & 0.41 & 11.98 & $377,891.32$ & 0.38 & 10.26 & $1,026.21$ & 1.03 & 4.81 & 480.76 & 0.48 & 4.42 & 441.86 & 0.44 \\
\hline $1971-72$ & 22.54 & $710,821.44$ & 0.71 & 14.70 & $463,569.45$ & 0.46 & 13.24 & $417,609.47$ & 0.42 & 8.31 & 831.15 & 0.83 & 5.42 & 542.04 & 0.54 & 4.88 & 488.30 & 0.49 \\
\hline $1972-73$ & 14.09 & $444,342.24$ & 0.44 & 13.92 & $439,049.60$ & 0.44 & 12.64 & $398,527.85$ & 0.40 & 5.20 & 519.56 & 0.52 & 5.13 & 513.37 & 0.51 & 4.66 & 465.99 & 0.47 \\
\hline $1973-74$ & 23.11 & $728,796.96$ & 0.73 & 13.01 & $410,306.33$ & 0.41 & 12.64 & $398,581.60$ & 0.40 & 8.52 & 852.16 & 0.85 & 4.80 & 479.76 & 0.48 & 4.66 & 466.05 & 0.47 \\
\hline $1974-75$ & 9.64 & $304,007.04$ & 0.30 & 11.49 & $362,345.61$ & 0.36 & 11.19 & $352,998.33$ & 0.35 & 3.55 & 355.47 & 0.36 & 4.24 & 423.68 & 0.42 & 4.13 & 412.75 & 0.41 \\
\hline $1975-76$ & 10.07 & $317,567.52$ & 0.32 & 12.84 & $404,849.51$ & 0.40 & 11.84 & $373,300.72$ & 0.37 & 3.71 & 371.32 & 0.37 & 4.73 & 473.38 & 0.47 & 4.36 & 436.49 & 0.44 \\
\hline $1976-77$ & 16.62 & $524,128.32$ & 0.52 & 12.42 & $391,769.51$ & 0.39 & 11.24 & $354,544.86$ & 0.35 & 6.13 & 612.85 & 0.61 & 4.58 & 458.09 & 0.46 & 4.15 & 414.56 & 0.41 \\
\hline 1977-78 & 21.56 & $679,916.16$ & 0.68 & 12.72 & $401,286.72$ & 0.40 & 12.44 & $392,368.03$ & 0.39 & 7.95 & 795.01 & 0.80 & 4.69 & 469.21 & 0.47 & 4.59 & 458.79 & 0.46 \\
\hline 1978-79 & 32.07 & $1,011,359.52$ & 1.01 & 16.01 & $504,972.52$ & 0.50 & 13.75 & $433,488.93$ & 0.43 & 11.83 & $1,182.56$ & 1.18 & 5.90 & 590.45 & 0.59 & 5.07 & 506.87 & 0.51 \\
\hline $1979-80$ & 33.06 & $1,042,580.16$ & 1.04 & 20.15 & $635,435.05$ & 0.64 & 15.63 & $492,968.20$ & 0.49 & 12.19 & $1,219.06$ & 1.22 & 7.43 & 743.00 & 0.74 & 5.76 & 576.42 & 0.58 \\
\hline $1980-81$ & 25.68 & $809,844.48$ & 0.81 & 16.70 & $526,650.31$ & 0.53 & 14.63 & $461,455.41$ & 0.46 & 9.47 & 946.93 & 0.95 & 6.16 & 615.80 & 0.62 & 5.40 & 539.57 & 0.54 \\
\hline $1981-82$ & 20.08 & $633,242.88$ & 0.63 & 17.48 & $551,259.26$ & 0.55 & 13.73 & $432,931.35$ & 0.43 & 7.40 & 740.44 & 0.74 & 6.45 & 644.57 & 0.64 & 5.06 & 506.22 & 0.51 \\
\hline
\end{tabular}




\section{References}

De Cesare G., Beyer Portner N., Boillat J. and Scleiss A. (1998), Modelling of erosion and sedimentation based on field investigation in Alpine reservoirs of hydropower schemes. German Coastal Engineering Research Council, parallel session 34 .

De Vente J. and Poesen J. (2005), Predicting soil erosion and sediment yield at the basin scale: Scale issue and semiquantitative models, Earth - Science Reviews, 71, 95-125.

De Vente J., Poesen J., Bazzzoffi B., Van Rompaey A. and Verstraeten G. (2006), Predicting catchment sediment yield in Mediterranean environments: the importance of sediment sources and connectivity in Italian drainage basins, Earth Surface Processes and Landforms, 31, 1017-1034.

Emmanouloudis D. and Filippidis E. (2002), A quantitative estimation model of mountainous watershed degradation. Kick-off workshop on IAHS, Decade of prediction in ungauged basins (PUB) - Hydrological Science on Mission, Brazil.

Emmanouloudis D., Christou O. and Filippidis E. (2003), Quantitative estimation of degradation in the Aliakmon river basin using GIS. Erosion Prediction in Ungauged Basins: Integrating Methods and Techniques. IAHS Publication, 279, 234.

Fannetti D. and Vezzoli L. (2007), Sediment input and evolution of lacustrine deltas: The Breggia and Greggio rivers case study (Lake Como, Italy), Quaternary International, 173-174 (SUPPL.), 113-124.

Gavrilovic S. (1962), A method for estimating the average annual quantity of sediments according to the potency of erosion. Faculty of Forestry, no. 26, p. 151-168. (In Serbian)

Gavrilovic S. (1970), Modern ways of calculating the torrential sediment and erosion mapping. In: Erosion, Torrents and Alluvial Deposits. Yugoslav Committee for International Hydrological decade, Belgrade. p. 85-100. (In Serbian)

Gavrilovic S. (1972), Engineering of Torrents and Erosion. Belgrade, pp. 292. (In Serbian)

Gavrilovic Z. (1988), The use of empirical method (Erosion Potential Method) for calculating sediment production and transportation in unstudied or torrential streams. In: White, W. R. (ed.), International Conference on River Regime. John Wiley \& Sons, Chichester, p. 411-422.

Globevnik L., Holjevic D., Petkovsek G. and Rubinic J. (2003), Applicability of the Gavrilovic method in erosion calculation using spatial data manipulation techniques. In: De Boer, D. H. (ed.), Erosion prediction in ungauged basins: integrating methods and techniques. IAHS publication, no. 279. IAHS, Wallingford, Oxfordshire, p. 224-233.

Grimm M., Jones R. and Montanarella L. (2002), Soil erosion risk in Europe. European Soil Bureau Institute for Environment \& Sustainability JRC Ispra.

Kalinderis I., Sapountzis M., Stathis D., Tziaftani F., Kourakli P. and Stefanidis P. (2009), The risk of sedimentation of artificial lakes, following the soil loss and degradation process in the wider drainage basin. Artificial lake of Smokovo case study (Central Greece). International Conference LANDCON 0905 "Global Change-Challenges for soil management-from degradation-through soil and water conservation-to sustainable soil management", Tara Mountain, Serbia.

Kotoulas D. (1972), The torrents of Southern Germany and Greece. Part. 1. Report No. 25, Munich, 1-177 (In German)

Koutsoyiannis D. and Xanthopoulos Th. (1999). Engineering Hydrology, Edition 3, 418 pages, National Technical University of Athens, Athens.

Lazarevic R. (1968a), Erosion in the Gvozdacka river basin - supplement to the instructions for erosion map elaboration, Bulletin of the Serbian Geographical Society, 49(2), 75-98. (In Serbian).

Lazarevic R. (1985), The new method for erosion coefficient determination - Z. Erosion - professional factsheet, 13; 54-61. (In Serbian)

Morgan R.P.C. (2005). Soil Erosion and Conservation, 3rd edition, Blackwell Publishing.

Panagoulia D., Zarris D. and Maggina K. (2004), An Assessment of the Interaction Between Storm Events and Sediment Transport, Proceedings of the $5^{\text {th }}$ International Synposium on Ecohydraulics, Aguatic Habitats: Analysis \& Restoration, (editors Diego Garsía de Jalón Lastra and Pilar Vizcaíno Martínez), IAHR Congress Proceedings, Vol.1, pp. 281-286, Madrid, 12-17 September, Spain. 
Panagoulia D. and Dimou G. (2005), Erosion, Transport and Deposition of Sediments, Lecture notes, InterDepartmental Postgraduate Course "Water Resources Science and Technology", National Technical University of Athens (NTUA), Athens.

Petras J., Kuspilic N. and Kunstek D. (2005), Some experience on the prediction of suspended sediment concentrations and fluxes in Croatia. Proceedings of Symposium SI held during the Seventh IAHS Scientific Assembly at Foz do Igacu, Brazil. IAHS, 292:179-184.

Rafaelli S., Peviani M. and Perez Ayala F. (1998), Study of sediment yield on the mountain Cuence del Rio Iruya (Argentina). IARH AMH, Hydraulic XVIII Latin American Conference, Oaxaca, Mexico. (In Spanish)

Renard K.G., Foster G.R., Weesies G.A. and Porter J.P. (1991), RUSLE: Revised Universal Soil Loss Equation, J.Soil Water Conserv., 46(1), 30-33.

Renard K.G., Foster G.R., Yoder D.C. and McCool D.K. (1994), RUSLE revisited: Status, questions, answers, and the future, J. Soil Water Conserv., 49(3), 213-220.

Salvati L., Kosmas C., Kairis O., Karavitis C., Acikalin S., Belgacem A., Solé-Benet A., Chaker M., Fassouli V., Gokceoglu C., Gungor H., Hessel R., Khatteli H., Kounalaki A., Laouina A., Ocakoglu F., Ouessar M., Ritsema C., Sghaier M., Sonmez H., Taamallah H., Tezcan L. and de Vente J. (2014), Unveiling soil degradation and desertification risk in the Mediterranean basin: a data mining analysis of the relationships between biophysical and socioeconomic factors in agro-forest landscapes, Journal of Environmental Planning and Management, DOI:10.1080/09640568.2014.958609.

Staut M. (2004), Recent erosional processes in the catchment of the Dragonja river. Unpublished graduate thesis. Faculty of Arts, University of Ljubljana, Ljubljana. (In Serbian)

Stefanidis P. (1995), The torrent problems in Mediterranean Areas (example from Greece). Proc. XX IUFRO World Congress. Finland 1995. Technical Session on Natural Disasters in Mountainous Areas, 51-60.

Stefanidis P., Myronidis D., Sapountzis M. and Stathis D. (1998), The torrent "Sklitrho" in Florina. Torrential Environment and torrent control system. Scientific Annals. Department of forestry and natural environment. Aristotelian University of Thessaloniki. 41, (2), 1275.

Tóth G., Montanarella L. and Rusco E. (2008), Threats to Soil Quality in Europe, European Commission, Joint Research Centre, Institute for Environment and Sustainability, Land Management and Natural Hazards Unit.

Wischmeier W.H. and Smith D.D. (1978), Predicting rainfall erosion losses: a guide to conservation planning. USDA Agricultural Handbook 537.

Zemljic M. (1971), Calculation of sediment load. Evaluation of vegetation as anti-erosive factor. Proceedings of the international symposium Interpraevent, Villach (Australia). (In French) 